AGRICULTURE AND BIOLOGY JOURNAL OF NORTH AMERICA

ISSN Print: 2151-7517, ISSN Online: 2151-7525

(C) 2010, ScienceHuß, http://www.scihub.org/ABJNA

\title{
Mango diseases in Egypt
}

\author{
Wafaa M. Haggag \\ Department of Plant Pathology National Research Center, Dokki, Cairo, Egypt. \\ *Corrosponded authur: Wafaa haggag@yahoo.com \\ ABSTRACT
}

\begin{abstract}
Mango (Mangifera indica L.) is universally considered one of the most important fruit crop in Egypt. Egypt produces 232,000 tone of mangos annually and exports moderate amounts (1500 tones) to 20 countries in the near East and Europe, FAO, 2000. It is expected that commercial and backyard plantings of mango trees will continue to increase. Mango suffers from several diseases at all stages of its life. All the parts of the plant, namely, trunk, branch, twig, leaf, petiole, flower and fruit are attacked by a number of pathogens including fungi, bacteria and algae. They cause several kinds of rot, die back, anthracnose, malformation, scab, necrosis, blotch, spots, mildew, etc. This fact sheet concentrates on the symptoms of the important mango diseases, the weather conditions conducive to disease development, and methods for control.
\end{abstract}

\section{ANTHRACNOSE}

Anthracnose, the most important mango disease, is caused by the fungus Colletotrichum gleosporioides. Flower blight, fruit rot, and leaf spots are among the symptoms of this disease (Arauz,2000). Infections on the panicles (flower clusters) start as small black or dark-brown spots. These can enlarge, coalesce and kill the flowers, greatly reducing yield. On leaves, anthracnose infections start as small, angular, brown to black spots. Depending on the prevailing weather conditions blossom blight may vary in severity from slight to a heavy infection of the panicles. Anthracnose is usually more serious in years when rain and heavy dews are more frequent during the critical periods of infection from the onset of flowering until fruit are about half size. Severe infection destroys the entire inflorescence resulting in no setting of fruits. Young infected fruits develop black spots, shrivel and drop off. Fruits infected at mature stage carry the fungus into storage and cause considerable loss during storage, transit and marketing . Varietal differences in susceptibility have been noted in Egypt., which maximum damage was observed on Alphons, whereas variety Tommi and Fagr Kelan was recorded to be resistant (Table 1). Since the fungus has a long saprophytic survival ability on dead twigs, the diseased twigs should be pruned and burnt along with fallen leaves for reducing the inoculum potential.

\section{POWDERY MILDEW}

Powdery mildew is caused by the fungus Oidium. Although a somewhat sporadic disease, it can cause severe crop loss due to flower and panicle infection and subsequent failure of fruit set (Figure 2) (Nofal and Haggag Wafaa, 2006). The disease is reported to cause approximately $20-80 \%$ per cent crop loss.
Powdery mildew is common in all over Egypt as ElBehera , El-Fayum, El-Monefia forword by El Ismilia Governorates. Powdery mildew is one of the most serious diseases of mango affecting almost all the varieties as cvs. Alfonso and Seddek. Meanwhile, Zebda, Hendi besenara and and Awies cultivars are moderate infection than the other cultivars (Table 1). The characteristic symptom of the disease is the white superficial powdery fungal growth on leaves, stalks of panicles, flowers and young fruits. The affected flowers and fruits drop pre-maturely reducing the crop load considerably or might even preven the fruit set. Rains or mists accompanied by cooler nights during flowering are congenial for the disease spread. The fungus parasitizes young tissues of all parts of the inflorescence, leaves and fruits. Powdery mildew occurs in the spring and is particularly destructive in years when the weather is cool and dry.

\section{MALFORMATION}

Malformation is widely prevalent in Egypt where more than 80 per cent of the trees suffer from this malady (Table 1) (Ploetz et al., 2002). Malformation affects vegetative and floral tissues of mango. The malformed panicles remain unproductive and are characterised by a compact mass of male flowers, greenish in colour and stunted in growth. Apical or axillary buds produce misshapen shoots with shortened internodes and dwarfed leaves which are brittle and recurve towards the supporting stem. The main and secondary rachis are thick and short and bear flowers with relatively larger bracts, sepals and petals as compared to normal flowers (Figure 3 ). The malformed panicles remain intact on the trees for a considerable period. Compact leaves formed at the apex of shoot or in the leaf axil, to form the bunchy 
top seedlings and are usually shallow with few tertiary roots. Floral aggregation may also appear on shortened primary axil of the inflorescence, which is further branched to secondary and tertiary branches, on which flowers are borne in clusters and no fruit or very poor fruit setting is observed. Infected inflorescence remains green for long time; no malformed heads dry up in black masses but persist on trees. More important, however, is the affect of malformation on fruit set: fruit in affected panicles either do not set or abort. The tap root may be Table 1. Susceptibility of fruti of different mango cultivars twisted and may show necrosis. Though research efforto made hitherts have not been able to ascertain its etiology, the complexity of the disorder is attributed cultural practices, nutritional, to many factors like, mites, fungal, viral, etc. hormonal imbalance. The fungus Fusarium subglutinans causes malformation. It is believed that the mango bud mite, Eriophyes mangiferae, is a vector of this pathogen that enhances infection by wounding host tissues while feeding on mango. The pathogen is spread by grafting and in infected nursery stock.

\begin{tabular}{l|ccc}
\multirow{2}{*}{ Cultivars } & \multicolumn{3}{c}{ Disease reaction: } \\
\cline { 2 - 4 } & Anthracnose & Powdery mildew & Malformation \\
\hline Alphonso & *HS & HS & HS \\
Timour & HS & S & HS \\
Sadeka & MR & HS & HS \\
Zebda & HS & M & S \\
Tommi & HR & HR & HR \\
Kett & HR & HR \\
Kent & H & HR & HR \\
Hendi Khasa & M & R & M \\
Hendi Sennara & R & M & S \\
FagrKelan & HR & MR & S \\
Awais & S & & \\
\hline
\end{tabular}

\section{DIEBACK}

*Disease reaction: $\mathrm{HR}=$ highly resistant; $\mathrm{R}=$ resistant; $\mathrm{MR}=$ moderately resistant; $\mathrm{S}=$ susceptible; and $\mathrm{HS}=$ highly susceptible

Die back is one of the serious diseases of mango in Egypt. The disease on the tree may be noticed at any time of the year but it is most conspicuous during Oct.-Nov. The disease is characterized by drying of twigs and branches followed by complete defoliation, which gives the tree an appearance of scorching by fire. Tip die back disease occurs on the branches/ trunk of infested trees that start drying slowly at first and suddenly branches become completely dried I killed resulting gummy substance oozes out or remains hanging on the tree. The dark area advances and young green twigs start withering first at the base and then extending outwards along the veins of leaf edges. The affected leaf turns brown and its margins roll upwards. At this stage, the twig or branch dies, shrivels and falls. This may be accompanied by exudation of gum. In old branches, brown streaking of vascular tissue is seen on splitting it longitudinally. The areas of cambium and phloem show brown discolouration and yellow gum like substance is found in some of the cells ( Ploetz and Ploetz, 2003).

\section{BACTERIAL CANKER}

Canker disease of mango, caused by a bacterium (Xanthomonas campestris pv. mangiferaeindicae), is prevalent in Egypt. Besides being pathogenic on several varieties of mango, the organism is capable of infecting wild mango, cashew nut and weeds as well. The disease causes fruit drop (10-70\%), yield loss (10-85\%) and storage rot (5-100\%). Many commercial cultivars of mango including Langra, Timor and Alfons are susceptible to this disease. Bacterial leaf spot is noticed on the leaves as angular water soaked spots or lesions, surrounded by clear holes. These become necrotic and dark brown and viscous bacterial exudates deposit on these necrotic portions that become corky and hard after drying. Sometimes, longitudinal cracks also develop on the petioles. Some of the similar signs are present in suffering mango orchards. Cankerous lesions appear on petioles, twigs and young fruits. The water soaked lesions also develop on fruits which later turn dark brown to black. They often burst open, releasing a highly contagious gummy ooze containg bacterial cells. The fresh lesions on branches and twigs are water soaked which later become raised and dark brown in colour with longitudinal cracks but without any ooze( Ploetz and Ploetz, 2003).

\section{ROOT ROT}

Root rot is also prevalent in almost all orchards; manifest itself as withering and drying of the plant from top to bottom and whole plant die up. Initially rootlets are affected and are rotten, later on the smaller, tertiary roots and ultimately the bigger, secondary and primary- main roots are infected which result in gradual decline of the plant and the plant die. 
Agric. Biol. J. N. Am., 2010, 1(3): 285-289
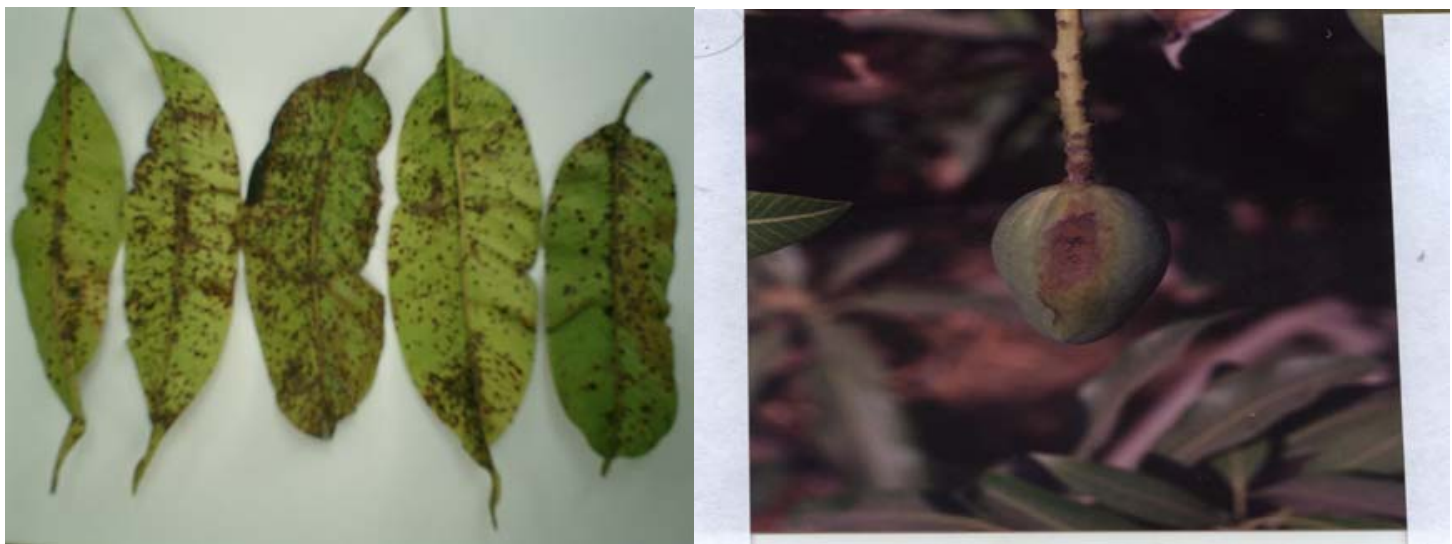

Fig 1. Anthracnose infections start as small, angular, brown to black spots in leaves and fruits

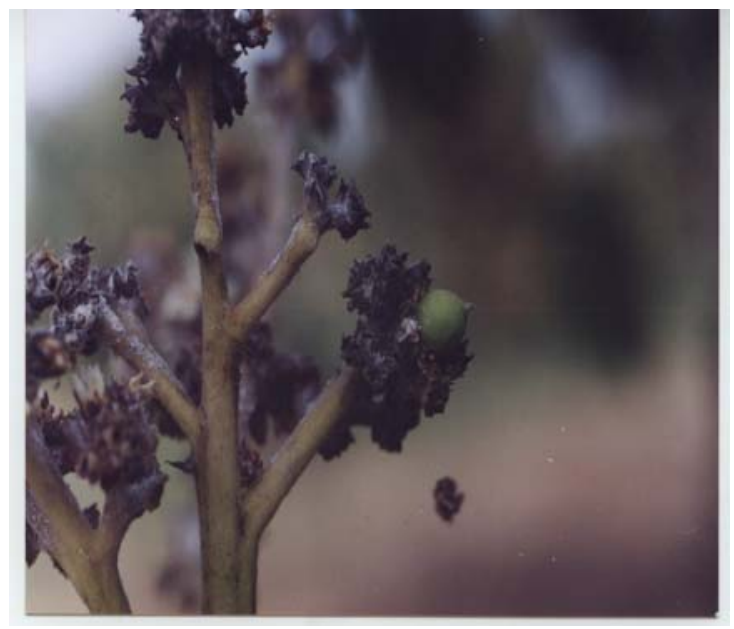

Fig 2. Severe powdery mildew infection of mango panicle flower cluster

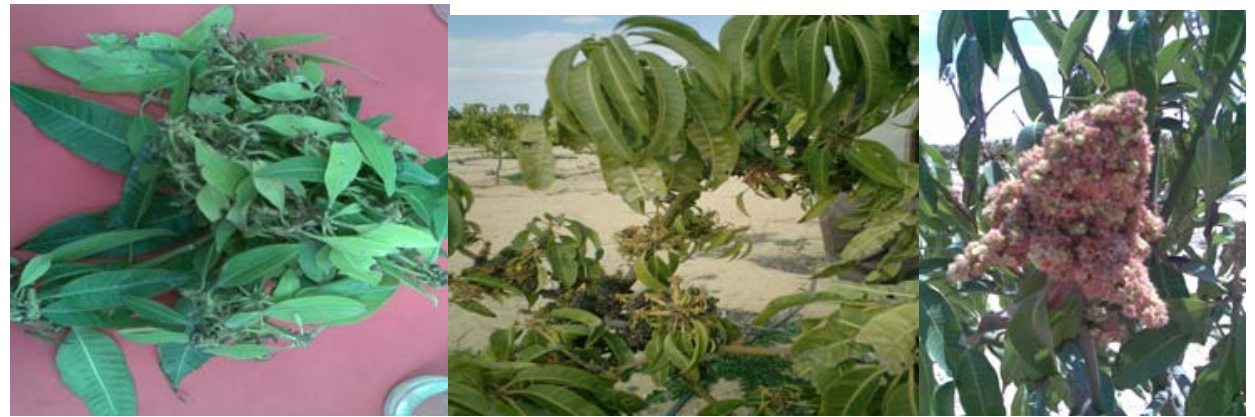

Fig 3. A malformed mango panicle in which leaves and floral have developed, a typical symptom. 
Agric. Biol. J. N. Am., 2010, 1(3): 285-289

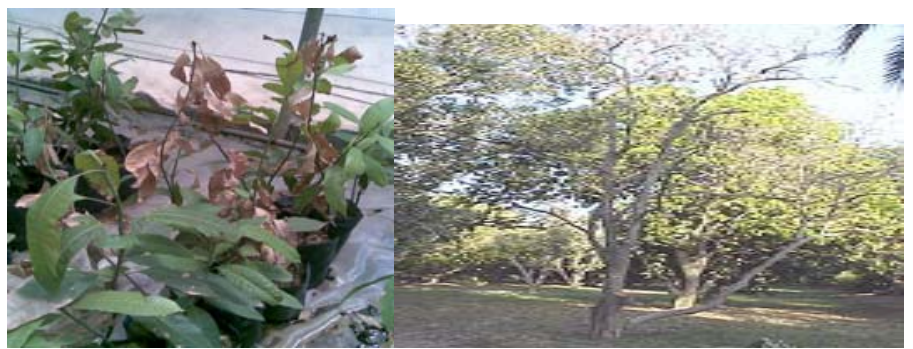

Fig 4. Mango decline: tip dieback and branch death in a young transplants (right) and trees (left)

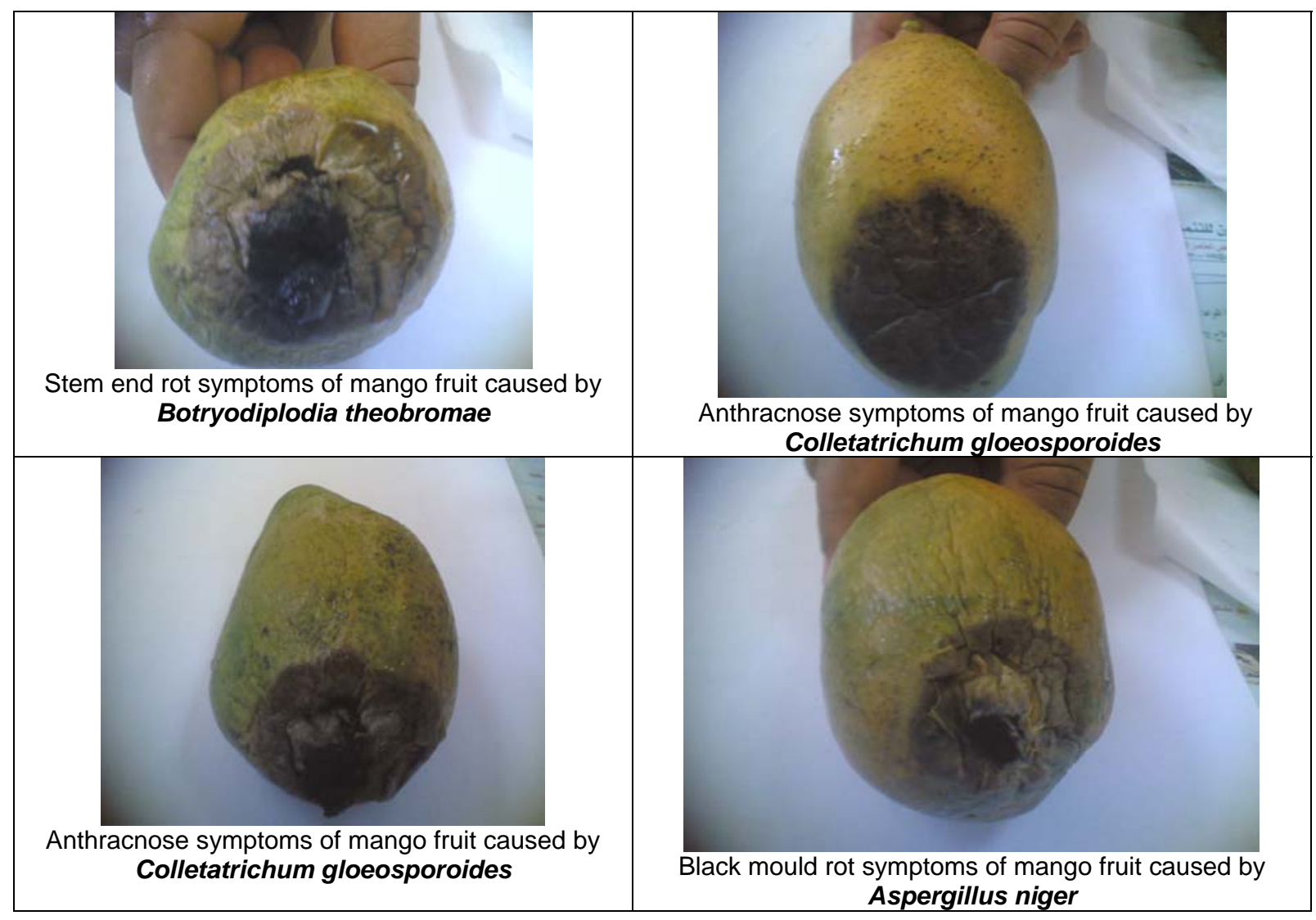

\section{VERTICILLIUM WILT}

Fig. 5 Postharvest diseases symptoms of mango fruits

Verticillium wilt, caused by the soilborne fungus Verticillium albo-atrum or $V$. dahliae is a disease of increasing importance to mango production ( Ploetz and Ploetz, 2003). The problem is usually observed in young trees planted on land previously cropped to vegetables that are also susceptible to this disease. The Verticillium fungus can survive in soil in a dormant state for at least 15 years. When trees are set in infested soil, the fungus returns to an active stage and invades the mango roots. As Verticillium colonizes and blocks the vascular (water-conducting) system, trees begin to exhibit symptoms of water stress. Trees decline and die back slowly in a more or less random fashion in the grove. Leaves wilt and die, often in a characteristic "one-sided" fashion, a key diagnostic feature. The dead leaves often remain attached to infected branches, giving the tree a "fired"appearance.

\section{POSTHARVESTED}

The comparatively low cost of fruit production combined with its high nutritive value make it an ideal dessert (Tripathi, and Dubey, 2004). Because of high moisture, temperature and the presence of nutritive contents the fruits are highly susceptible to attack by different pathogenic fungi. Being highly perishable, 
mango fruits have to be marketed immediately after harvest. The postharvest loss of mango is up to 17$36 \%$. The mango tree and more especially the fruit is the host of a large number of pathogens among which fungi could be major agents of fruit rot after harvest in the world and as in Egypt. Fungal pathogens involved in mango rotting after harvest include Colletotrichum gloeosporioides responsible for mango anthracnose, Alternaria alternata and $A$. tenuissima that cause alternariose, Botryodiplodia theobromae and Dothiorella spp. responsible for stem end rot and Phoma mangiferae. In Egypt, C.gloeosporoids which cause anthracnose disease show a highly frequency fungi isolated from decay fruits by $47.0 \%$ from both tested varieties ,followed by B.theobromae which cause stem-end rot of mango fruits by $38.7 \%$. On the other hand, A.alternate, A.niger and R.stolonifer were recorded medium frequency isolated fungi by $18.1,17.7$ and $17.3 \%$, respectively. Meanwhile, Pencillium sp. and Mucor sp. recorded lower percentage of frequency fungi from both tested mango verities. Kent and Kett cvs. were more tolerance to infection with all isolated fungi than others.

\section{ACKNOWLEDGMENTS}

This document from Project "New applied approaches to promote productivity and Quality of some fruit crops (Mango), Number 8040971" Funded by National Research Centre, Cairo, Egypt; PI, Prof. Wafaa Haggag

\section{REFERENCES}

Arauz, L.F. (2000). Mango anthracnose: Economic impact and current options for integrated management. Plant Dis. 84: $600-611$

Nofal, M.A. and Haggag ,Wafaa, M. (2006). Integrated pest management for the control of powdery mildew on mango trees in Egypt. Crop Protection. 25: 480-486.

Ploetz, R. and Ploetz, R. (2003). Diseases of mango. Diseases of tropical fruit crops 327-363

Ploetz R.;Zheng Q.I.;Vázquez Á.;Sattar M.A.A.(2002). Current status and impact of mango malformation in Egypt . Intl J Pest Management. 48 ( 4) : 279-285.

Tripathi, P. and Dubey, N.K. (2004). Exploitation of natural products as an alternative strategy to control postharvest fungal rotting of fruit and vegetables. Postharvest Biol Technol 32:235-245. 